\title{
Dry Bean Morpho-Physiological Responses to Gradual Weed Biomass Accumulation
}

\author{
Hossein GHAMARI*, Goudarz AHMADVAND \\ Bu-Ali Sina University, Faculty of Agriculture, Department of Agronomy and Plant Breeding, \\ Hamedan,Iran; Ghamari130@gmail.com (*orresponding author)
}

\begin{abstract}
Field study was carried out in 2011 in west of Iran to assess responses of dry bean (Phaseolus vulgaris L.) morpho-physiological traits to gradual weed biomass accumulation. The treatments consisted of two different periods of weed interference, which weeds either infested the plots or removed for an increasing duration of time $(0,10,20,30,40,50$ days $)$ after crop emergence. Relative dominance and relative importance of weed species fluctuated over the crop cycle. As the duration of weed interference was increased, a declining trend of crop growth rate (CGR) was observed. When weeds were allowed to compete with crop throughout the crop cycle, maximum value of CGR was decreased from $25.57 \mathrm{~g} \mathrm{~m}^{-2}$ days in full season weed free treatment to $16.78 \mathrm{~g} \mathrm{~m}^{-2}$ days in full season weed infested treatment. Effect of treatments on leaf area index (LAI) was significant. Weed removal increased LAI but it could not significantly affect this trait, at the early of growing season. Weed interference caused a significant reduction on number of branches. The minimum number of branches was registered in full season weed infested treatment ( 2.58 branches per plant), while the maximum one was observed in the full season weed free treatment ( 4.25 branches per plant). Weed competition severely reduced crop yield. At 10 and 20 days after crop emergence, weed infestation could not significantly affect the yield. A negative relationship between weeds' dry matter accumulation and LAI as well as number of branches was observed which signify the vulnerability of these morpho-physiological traits to weed competition.
\end{abstract}

Keywords: CGR, competition, dry matter, leaf area index, number of branches

\section{Introduction}

The common bean (Phaseolus vulgaris L.) is an important grain legume and it serves as a vital cheap source of protein, vitamins and mineral nutrients (Broughton et al., 2003). It is a source of important nutritional factors such as flavonoids, vitamin A (high content in carotenoids, including beta-carotene), dietary fibers, potassium, folate, iron, magnesium, thiamin, riboflavin, copper, calcium, phosphorous, omega-3 fatty acids and niacin (Stagnari and Pisante, 2011). Common bean belongs to plants sensitive to weed competition. When weeds accompany common bean during the entire growing season, grain's yield can be reduced even about 90\% (Blackshaw, 2001). Burnside et al. (1998) stated that weed presence can cause a severe reduction in yield of dry been. Wilson et al. (1990) informed that there is a negative relation between weeds' dry matter and the final yield of common bean. Low production of crop in weed infestation conditions is the result of harmful change in crop morpho-physiology traits such as leaf area index (LAI) and number of branches in response to lack of environmental resources. Since LAI has a major role in light absorption and photosynthesis, it subsequently can affect the final yield. Cavero et al. (1999) reported that corn LAI was remarkably reduced because of the weed competition. Hargood et al. (1981) stated that crop growth rate (CGR) and LAI is suitable scales of crop function which can affect competitiveness. CGR presents crop dry matter accumulation in a specific period of time during growing season; therefore it can demonstrate crop ability in capture of environmental resources. Fernandez et al. (2002) observed a declining trend in corn CGR under weed competition condition.

Growth and yield of crop are substantially reduced by weed competition for nutrients, water and light, therefore weed control is one the most important considerations in crop production. Manual weed removing is not only very expensive due to high requirements in man power, but also ineffective because the timing of weed control operations (Ngouajio et al., 1997). Therefore, practice of using herbicides is frequent in common bean farms. Today, excessive and improper application of herbicides has been leaded to weed resistance and environmental issues (Woolley et al., 1993). Since a considerable cost of production is allocated to weed control, production techniques should be designed to reduce herbicide applications in order to guide against weed resistance and environmental damage (Hall et al., 1992). In order to realize the potential of more ecological approaches to weed management that would reduce reliance on herbicides, the underlying processes of crop and weed competition must be understood. Therefore, the objective of this research was to assess responses of some dry bean morpho-physiological traits to different weed competition conditions. 


\section{Materials and methods}

The experiment was conducted in the year 2011 at the Agricultural Research Station of Hamedan located in west of Iran (34 $4^{\circ} 52^{\prime} \mathrm{N}$ latitude, $48^{\circ} 32^{\prime} \mathrm{W}$ longitude and $1741.5 \mathrm{~m}$ a.s.l.). The soil had a loamy texture containing $35 \%$ sand, $40.6 \%$ silt and $24.4 \%$ clay, with a $\mathrm{pH}$ of 8.08 . The climate is moderate, with average annual rains of 335 $\mathrm{mm}$. Before sowing, the soil was submitted to plowing and harrowing. Fertilizer applications were based on soil test recommendations at the rates of $100 \mathrm{~kg} \mathrm{ha}^{-1}$ urea and 100 $\mathrm{kg} \mathrm{ha}^{-1}$ super phosphate triple. Potassium fertilizer was not used. The cultivar 'NAZ' was planted manually with 50 $\mathrm{cm}$ between rows and $10 \mathrm{~cm}$ between plants in row at the depth of $5 \mathrm{~cm}$. The crop was irrigated after sowing and repeated approximately each week base on weather conditions.

Each experimental plot was $6.0 \mathrm{~m}$ long with 5 rows. A randomized block design with three replications was adopted. Twelve treatments were arranged in a factorial distribution of six periods of competition $(0,10,20,30$, 40 and 50 DAE) and two weed groups (weedy and weedfree). In the first group, plants were kept under weed interference up to the periods of $0\left(\mathrm{WF}_{\mathrm{T}}\right), 10\left(\mathrm{WI}_{10}\right), 20$ $\left(\mathrm{WI}_{20}\right), 30\left(\mathrm{WI}_{30}\right), 40\left(\mathrm{WI}_{40}\right)$ and $50\left(\mathrm{WI}_{50}\right) \mathrm{DAE}$, and thereafter weeds were eliminated; in the second group, plants were kept free of weed competition up to the periods of $0\left(\mathrm{WI}_{\mathrm{T}}\right), 10\left(\mathrm{WF}_{10}\right), 20\left(\mathrm{WF}_{20}\right), 30\left(\mathrm{WF}_{30}\right), 40$ $\left(\mathrm{WF}_{40}\right)$ and $50\left(\mathrm{WF}_{50}\right)$ DAE, and thereafter weeds were allowed to grow. Elimination of weeds was done manually. Weeds were sampled at the end of the weed infested period of each treatment quadrates with internal area of 1.0 $\mathrm{m}^{2}$ were randomly placed two times in the plot, and every weed was cut close to the ground, separated by species, counted, oven dried $\left(75^{\circ} \mathrm{C}\right)$ and weighed. These data were used for calculation of relative importance and relative dominance, according to the methodology proposed by Mueller-Dombois and Ellemberg (1974). Relative importance consists of the frequency of each species compared to other species in the weed community; relative dominance consists of the dry mass of each species compared to the biomass of the whole weed community.

Crop sampling was started 14 days after emergence and repeated 6 times with a 14 days interval. In each sampling, 5 plants were harvested and after measuring LAI, samples were dried at $75^{\circ} \mathrm{C}$ for 48 hours and then weighted. To determine crop growth rate (CGR) first primary data (dry matter) were transformed to natural logarithm to stabilize variance. The relationship between time $(t)$ and the transformed primary crop variable $[\ln (\mathrm{DM})]$ can be expressed as presented in the following equation (Heggenstaller $e t$ al., 2009):

$$
\ln (D M)=f_{D M}(t)
$$

Crop growth rate (CGR), was calculated as the first derivative of DM equation (Heggenstaller et al., 2009):

$$
\mathrm{CGR}=f_{D M}(t) \cdot \exp \left[f_{D M}(t]\right.
$$

In each treatment maximum LAI was determined and those data was used for analysis of variance. At the crop maturity, in each plot an area of $2.0 \mathrm{~m}$ long corresponding to the central area in the middle of two rows was harvested by hand and number of branches, number of pods and seed yield was measured. Data were submitted to analysis of variance considering the significance level of 5\% using PROC ANOVA procedure in SAS software (SAS Institute, 1999).

\section{Results and discussion}

Among weeds, Chenopodium album, Amaranthus retroflexus, Amaranthus blitoides and Convolvulus arvensis were the most predominant weeds. Relative dominance of these species showed a fluctuation over the crop cycle. At 20 days after crop emergence $C$. Album had more relative dominance than the others. At $40 \mathrm{DAE}$ the most relative dominance value belonged to $A$. retroflexus and $A$. blitoides, respectively. $C$. arvensis, approximately showed

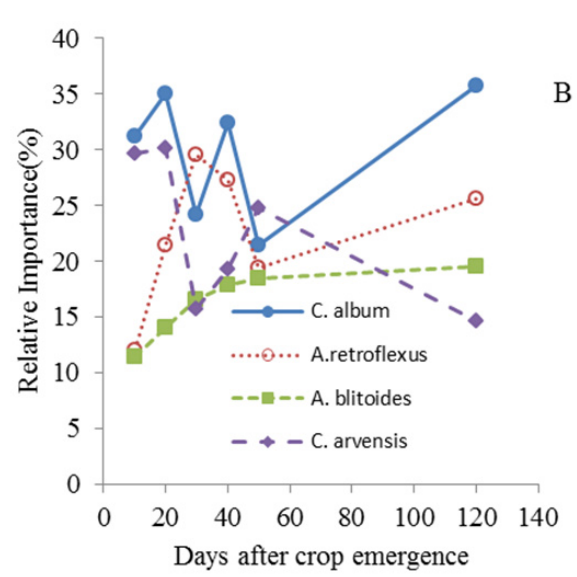

Fig. 1. Evolution of the relative dominance (A) and relative importance (B) for major weeds over time (days after crop emergence) in plots cultivated with dry bean 

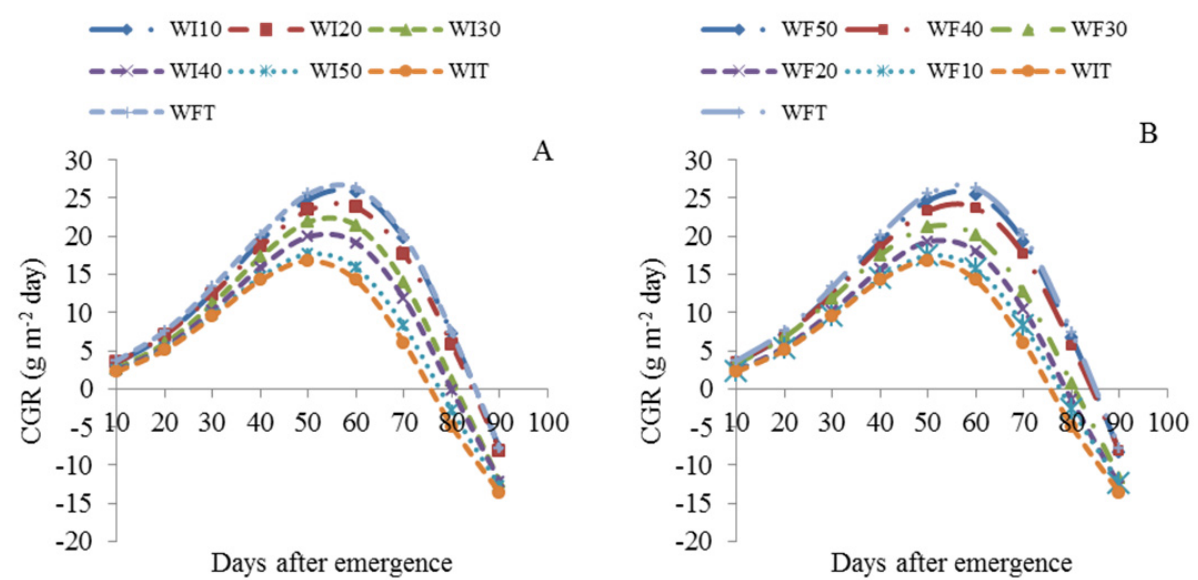

Fig. 2. Effect of increase in duration of weed interference (A) and weed free periods (B) on crop growth rate (CGR) of dry bean. $\mathrm{WI}_{10}, \mathrm{WI}_{20}, \mathrm{WI}_{30}, \mathrm{WI}_{40}$ and $\mathrm{WI}_{50}$ : weed infested periods until 10, 20, 30, 40 and 50 days after crop emergence, respectively; $\mathrm{WF}_{10}, \mathrm{WF}_{20}, \mathrm{WF}_{30}$, $\mathrm{WF}_{40}$ and $\mathrm{WF}_{50}$ : weed free periods until 10, 20, 30, 40 and 50 days after crop emergence, respectively; $\mathrm{WI}_{\mathrm{T}}$ and $\mathrm{WF}_{\mathrm{T}}$ : weed competition and weed control throughout growing season, respectively

a descending trend over time (Fig. 1A). The species with the highest relative importance at $20 \mathrm{DAE}$ were $C$. album, C. arvensis, $A$. retroflexus and $A$. blitoides, respectively. At $50 \mathrm{DAE}, C$. arvensis became the dominant species. At 120 DAE, highest relative importance belonged to $C$. album and $A$. retroflexus, respectively (Fig. 1B).

During the growing season, in all treatments, CGR gradually increased and reached to a maximum amount approximately at 55 DAE. Afterwards, because of aging and abscission of old leaves and probably decrease in the ability of the crop photosynthesis, CGR was reduced (Fig. 2). As the duration of weed interference was increased, a reduction in CGR value was observed (Fig. 2A). In contrast, weed removal increased this crop trait. The most value of CGR belonged to $\mathrm{WF}_{\mathrm{T}}$ with the amount of 25.57 $\mathrm{g} \mathrm{m}^{-2}$ day $^{-1}$ at 55 DAE (Fig. 2B). Cathcart and Swanton (2004) indicated that increase in duration of weed infested periods, reduced corn CGR. This phenomenon can be result of adverse effect of competition on photosynthesis by means of shading and reduction in leaf area which consequently can limit the crop dry matter accumulation.

Treatments had a significant effect on LAI (Tab. 1). Weed infested treatments caused a reduction in LAI while weed free treatments had a positive effect, so that crop LAI showed an increasing trend over them (Tab. 2). This result is in agreement with Cox et al. (2006) who stated that weed interference in the early growing season caused a reduction in corn LAI. WF ${ }_{10}$ and $\mathrm{WF}_{20}$ did not have any significant difference compared to $\mathrm{WI}_{\mathrm{T}}$. This indicates that early weed removal cannot prevent from adverse impact of weeds on crop LAI.

Weed competition had a severe effect on number of branches. This crop trait showed a declining trend with prolonged delay in weed control. Effect of weed-free treatments was contrary and an ascending trend of number of branches was observed in those treatments (Tab. 2). Among treatments minimum number of branches was registered in $\mathrm{WI}_{\mathrm{T}}$ (2.58 branches per plant), while the maximum one ( 4.25 branches per plant) was recorded in $\mathrm{WF}_{\mathrm{T}}$ (Tab. 2). Adverse effect of weed competition on number of branches has also been reported on soybean (Akey et al., 1990; Fageiry, 1987). Effect of treatments on pods number was significant (Tab. 1). Weed removal periods increased pods number. In contrast, this crop trait was adversely affected by weed interference and gradually decreased over weed infested treatments (Tab. 2). There was no any significant difference between $\mathrm{WF}_{50}$ and $\mathrm{WF}_{\mathrm{T}}$ (Tab. 2). This phenomenon implying that weed control more than 50 DAE cannot cause a significant increase in number of pods. Saxena et al. (1996) observed same result on chickpea.

Tab. 1. Analysis of variance for leaf area index (LAI), number of branches, number of pods and yield of common bean at different treatments of weed interference and weed free periods

\begin{tabular}{cccccc}
\hline \multirow{2}{*}{ Source of variation } & \multirow{2}{*}{ D.F. } & \multicolumn{4}{c}{ Means of squares } \\
\cline { 3 - 6 } & & LAI & No. Branches & No. Pods & Yield \\
\hline Replication & 2 & $0.20^{\text {ns }}$ & $0.55^{\text {ns }}$ & 10.86 & 337180.16 \\
Treatment & 11 & $3.40^{*}$ & $1.09^{* *}$ & 23.76 & $1268589.73^{* *}$ \\
Error & 22 & 0.34 & 0.33 & 3.27 & 99563.34 \\
C.V $(\%)$ & & 12.81 & 17.69 & 19.79 & 15.56 \\
\hline
\end{tabular}

ns, ${ }^{*}$ and ${ }^{* *}$ : Non-significant, significant at $5 \%$ and $1 \%$ probability levels, respectively 
Tab. 2. Means comparison for leaf area index (LAI), number of branches, number of pods and yield of common bean at different treatments of weed interference and weed free periods using LSD test

\begin{tabular}{ccccc}
\hline Treatments & LAI & $\begin{array}{c}\text { No. branches } \\
\text { per plant }\end{array}$ & $\begin{array}{c}\text { No. pods } \\
\text { per plant }\end{array}$ & $\begin{array}{c}\text { Yield }(\mathrm{Kg} \\
\text { ha }\end{array}$ \\
\hline $\mathrm{WI}_{10}$ & $5.90 \mathrm{ab}$ & $4.10 \mathrm{ab}$ & $12.56 \mathrm{ab}$ & $2805.10 \mathrm{a}$ \\
$\mathrm{WI}_{20}$ & $5.10 \mathrm{bc}$ & $3.93 \mathrm{abc}$ & $11.43 \mathrm{abc}$ & $2766.20 \mathrm{a}$ \\
$\mathrm{WI}_{30}$ & $4.50 \mathrm{~cd}$ & $3.11 \mathrm{dc}$ & $8.23 \mathrm{def}$ & $1739.70 \mathrm{bc}$ \\
$\mathrm{WI}_{40}$ & $4.00 \mathrm{de}$ & $2.96 \mathrm{dc}$ & $7.83 \mathrm{defg}$ & $1469.80 \mathrm{~cd}$ \\
$\mathrm{WI}_{50}$ & $3.70 \mathrm{de}$ & $2.76 \mathrm{~d}$ & $6.97 \mathrm{efg}$ & $1320.70 \mathrm{~cd}$ \\
$\mathrm{WI}_{\mathrm{T}}$ & $3.01 \mathrm{e}$ & $2.58 \mathrm{~d}$ & $5.01 \mathrm{~g}$ & $1168.30 \mathrm{~d}$ \\
$\mathrm{WF}_{10}$ & $3.30 \mathrm{e}$ & $2.64 \mathrm{~d}$ & $5.88 \mathrm{fg}$ & $1378.50 \mathrm{~cd}$ \\
$\mathrm{WF}_{20}$ & $3.80 \mathrm{de}$ & $2.81 \mathrm{~d}$ & $6.91 \mathrm{efg}$ & $1770.60 \mathrm{cb}$ \\
$\mathrm{WF}_{30}$ & $4.60 \mathrm{dc}$ & $3.08 \mathrm{~cd}$ & $9.01 \mathrm{cde}$ & $2019.70 \mathrm{~b}$ \\
$\mathrm{WF}_{40}$ & $5.29 \mathrm{abc}$ & $3.13 \mathrm{bcd}$ & $10.04 \mathrm{bcd}$ & $2190.30 \mathrm{~b}$ \\
$\mathrm{WF}_{50}$ & $5.80 \mathrm{ab}$ & $3.92 \mathrm{abc}$ & $12.13 \mathrm{ab}$ & $2832.10 \mathrm{a}$ \\
$\mathrm{WF}_{\mathrm{T}}$ & $6.21 \mathrm{a}$ & $4.25 \mathrm{a}$ & $13.66 \mathrm{a}$ & $2869.10 \mathrm{a}$ \\
\hline
\end{tabular}

Means followed by the same letter $(s)$ within a column are not significantly different at the $\mathrm{p}=0.05$ level using LSD test. $\mathrm{WI}_{10}, \mathrm{WI}_{20}, \mathrm{WI}_{30}, \mathrm{WI}_{40}$ and $\mathrm{WI}_{50}$ : weed infested periods until 10, 20, 30, 40 and 50 days after crop emergence, respectively; $\mathrm{WF}_{10}$, $\mathrm{WF}_{20}, \mathrm{WF}_{30}, \mathrm{WF}_{40}$ and $\mathrm{WF}_{50}$ : weed free periods until 10, 20, 30, 40 and 50 days after crop emergence, respectively; $\mathrm{WI}_{\mathrm{T}}$ and $\mathrm{WF}_{\mathrm{T}}$ : weed competition and weed control throughout growing season, respectively
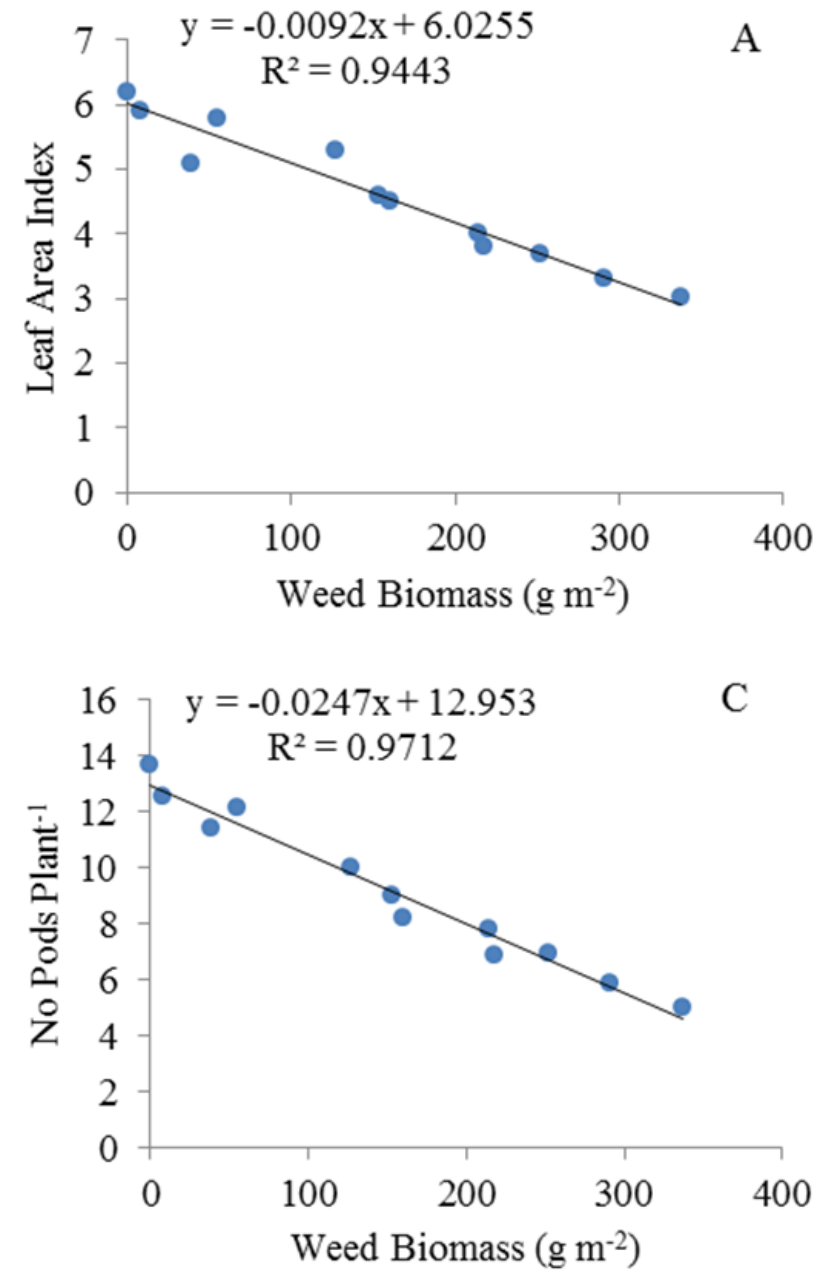

Grain yield was intensively reduced when weeds were allowed to compete with the crop. A 60\% reduction in grain yield was observed in $\mathrm{WI}_{\mathrm{T}}$ compared with $\mathrm{WF}_{\mathrm{T}}$ (Tab. 2). On the contrary, as the crop kept weed free, a significant increase in grain yield was observed. Until 20 DAE weed competition did not have any significant effect on yield reduction. Additionally, weed removal more than 50 DAE did not have a statistically significant difference with $\mathrm{WF}_{\mathrm{T}}$ (Tab. 2). This is in line with Stagnari and Pisante (2011) who indicated that in French bean severe yield reduction was observed when weeds were left to interfere with the crop throughout the crop cycle. At the early growing season, because of plenty of growth resources and low density of weeds, competition does not have any severe adverse effect on common bean. After $20 \mathrm{DAE}$, weeds are grown enough to strongly compete with crop for capturing essential resources. Therefore, after this period weed interference has a significant negative effect on yield. Thus, during this period weed removal can help crop to develop its canopy to improve its ability against weeds. After 50 DAE of weed removal, crop canopy have been adequately developed to suppress the new weeds which may be grown afterwards.
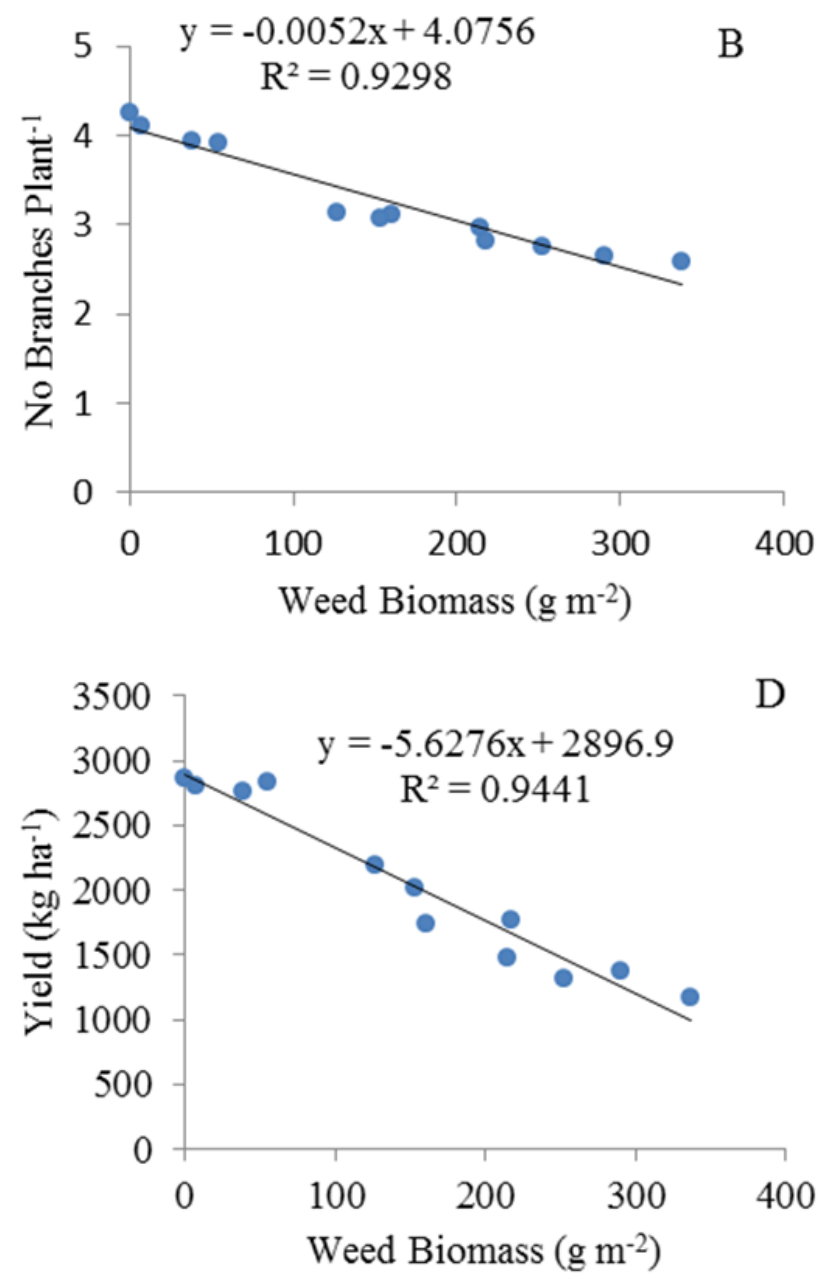

Fig. 3. Relationship between weed biomass and leaf area index (A), number of branches (B), number of pods (C), and yield (D) of dry bean 
78

Fig. 3 represents the relationship between weed dry matter accumulation and some traits of dry bean. A negative relationship between weed biomass and LAI, number of branches, pods number and grain yield was observed. More accumulation of weed dry matter had more negative effect on dry bean yield and development. Accumulation of weeds dry matter is the result of capturing essential resources such as light, water and mineral nutrients. Since in agro-ecosystems these resources are often limited, therefore it can be concluded that when weeds dry matter increases, reduction in crop growth is inescapable.

\section{Conclusions}

Relative dominance and relative importance of weed species fluctuated over the growing season. Therefore, harmful effect of a specific species should be changed during the crop cycle. Weed competition caused a severe reduction of LAI. This phenomenon can adversely affect the photosynthesis ability and assimilation of the crop which consequently can affect dry matter accumulation. Thus, declining trend of CGR in weed infested treatments can be the result of LAI reduction. Increase in duration of weed interference decreased pods number. This incident may be the consequence of detrimental effect of competition on number of branches. Since pods number is one of the major yield components of dry bean, therefore any decrease in it can harmfully affects the final yield.

\section{References}

Akey WC, Juric TW, Dekker J (1990). Competition for light between velvet leaf (Abutilon theophrastii) and soybean (Glycine max). Weed Research 30:403-411.

Blackshaw RE (2001). Weed management in beans. Agricultural and agrifood Canada, Leth Bridge. Website maintained by Infoltarvest. Broughton JW, Hernandez G, Blair M, Beebe S, Gepts P, Vanderleyden J (2003). Beans (Phaseolus spp.)model food legumes. Plant Soil 252:55-128.

Burnside OC, Weinse MJ, Holder BJ, Weisberg S, Ristau EA, Johnson MM, Cameron JH (1998). Critical period for weed control in dry bean (Phaseolus vulgaris). Weed Sci 46:301306.

Cathcart RJ, Swanton CJ (2004). Nitrogen and green foxtail (Setaria viridis) competition effects on corn growth and development. Weed Sci 52:1039-1049.
Cavero J, Zaragoza M, Suso DT, Pardo PN (1999). Competition between maize and Datura stramonium in an irrigated field under semi-arid conditions. Weed Res 39:255-231.

Cox JW, Hahn RR, Stachowski PJ (2006). Time of weed removal with glyphosate affects corn growth and yield components. Agron J 98:349-353.

Fageiry KA (1987). Weed control in soybean (Glycine max) in vertisols of Sudan. Trop Pest Manag 33:220-223.

Fernandez ON, Vignolio OR, Requesens EC (2002). Competition between corn (Zea mays) and Bermuda grass (Cynodon dactylon) in relation to the crop plant arrangement. Agron J 22:293-305.

Hall MR, Swanton CJ, Anderson GW (1992). The critical period of weed control in grain corn (Zea mays). Weed Sci 40:441-447.

Hargood ES, Bauman JT, Williams JL, Schreiber MM (1981). Growth analysis of soybean (Glycine max L.) in competition with jimson weed (Datura stramonium L.). Weed Sci 6:572574.

Heggenstaller AH, Liebman M, Anex RP (2009). Growth analysis of biomass production in sole-crop and double-crop corn systems. Crop Sci 49:2215-2224.

Mueller-Dombois D, Ellemberg H (1974). Aims and Methods of Vegetation Ecology. John Willey \& Sons, New York.

Ngouajio M, Foko J, Fouejio D (1997). The critical period of weed control in common bean (Phaseolus vulgaris L.) in Cameroon. Crop Prot 16:127-133.

SAS Institute. 1999. The SAS system for Windows. Version 9.1 SAS Inst., Cary, NC.

Saxena NP, Saxena MC, Johnson J (1996). Adaptation of chickpea in the West Asia and north Africa Region. ICARDA 3:111-120.

Stagnari F, Pisante M (2011). The critical period for weed competition in French bean (Phaseoulus vulgaris L.) in Mediterranean areas. Crop Prot 30:179-184.

Wilson JR, Wicks GA, Fenter CR (1990). Weed control in field bean sustainable agriculture systems. Weed Technol 8:403407.

Woolley BL, Michaels TE, Hall MR, Swanton CJ (1993). The Critical period of weed control in white bean. Weed Sci 41:180-184. 